\title{
KEBO-KEBOAN DAN IDER BUMI SUKU USING: Potret Inklusivisme Islam di Masyarakat Using Banyuwangi
}

\author{
Ahmad Kholil \\ Fakultas Humaniora dan Budaya UIN Maulana Malik Ibrahim Malang \\ Jalan Gajayana No. 50 Malang. Telp. 081807765237 \\ email:khumi2005@yahoo.co.id
}

Abstract

This writing presents a discussion on one of cultural heritage in Indonesia which is in the form of magical ceremony having religious nuance. Several aspects of this ceremony, for instance, Animism and Hinduism values are clearly observable, especially in several form and physical orders; on most aspects, however, the aforementioned values trail are obscure as old traditions. Even though the values are considered as old heritage, by polishing and adapting certain creation, the more perceptible value and belief in this ceremony is Islam transcendentalist and humanist. Ider bumi and slametan are the two of cultural heritage having Islamic nuance, while kebo-keboan is an embodiment of Hinduism cultural heritage. In Alasmalang, kebo-keboan ceremony has religious orientation praying to the God for acquiring good harvest, blessed business and achieving wishes. Regarding ider bumi ceremony, which is practiced in most of Using society, is conducted by going around the village while reading kalimah toyyibah and resounding adzan in every side of village. This ceremony's purpose is to protect the village from any kind of annoyance from human being and devil. Furthermore, socially, kebo-keboan and ider bumi function as harmony keeper among the villagers, nature and with everything in the environment.

Key words: culture, social awareness, ider bumi, kebo-keboan

Abstrak

Tulisan ini membahas salah satu kekayaan budaya bangsa yang menjelma dalam upacara magic bernuansa keagamaan. Pada beberapa sisi masih tampak kental sebagai warisan budaya lama, baik animisme maupun hinduisme, terutama dalam bentuk dan tatanan fisik, tetapi di sebagian besar yang lain sudah tinggal jejak yang samar sebagai warisan lama. Meskipun sebagai warisan leluhur, dengan polesan dan kreasi tertentu, yang tampak sekarang justru nilai dan tradisi Islam yang transendentalis dan humanis. Warisan budaya yang bercita rasa islami itu seperti ider bumi dan slametan, sementara yang masih bernuansa hinduisme adalah kebo-keboan. Kebokeboan di Alasmalang mempunyai orientasi relijius berupa permohonan kepada Gusti Allah Yang Maha Kuasa agar tanaman, usaha dan tujuan yang hendak diraih mendapat perkenan dan berhasil sesuai harapan. Sementara ider bumi, yang dipraktikkan di sebagian besar masyarakat Using, keliling kampung dengan membaca kalimah thoyyibah dan mengumandangkan adzan di setiap sudut desa adalah bertujuan untuk melindungi desanya dari segala macam gangguan, dari makhluk kasar maupun halus. Di samping kedua tujuan itu, kebo-keboan dan ider bumi ini juga memiliki fungsi sosial, 
yaitu menjaga kerukunan sosial atau keharmonisan hubungan dengan sesama, alam semesta, dan dengan segala yang ada di lingkungan hidup manusia.

Kata kunci: budaya, kesadaran sosial, ider bumi, kebo-keboan

\section{Pendahuluan}

Bila melihat beberapa ekspresi budaya masyarakat muslim di Jawa, akan diperoleh kesimpulan bahwa mereka memiliki kesadaran sejarah yang cukup baik, sekaligus apresiatif terhadap warisan leluhur. Kesadaran masyarakat itu tercermin di antaranya dari sikap sosial keberagamaannya yang mengakomodir tradisi atau budaya lokal dalam berbagai kemasan. Contoh umum untuk hal ini adalah tradisi kenduri atau slametan untuk berbagai peristiwa yang dianggap perlu penghormatan khusus, semisal hal-hal yang berhubungan dengan kelahiran, pernikahan bahkan juga kematian. Selain hal tersebut, peristiwa lain yang dianggap mempunyai nilai khusus dalam perjalanan kehidupan manusia juga diiringi dengan kenduri, misalnya menempati rumah baru, hendak melakukan perjalanan jauh, mendapat anugerah berupa rizki atau pekerjaan, memulai cocok tanam dan lain sebagainya.

Tidak berbeda dengan daerah lain di Jawa, Banyuwangi juga kaya dengan warisan budaya leluhur yang masih tetap terpelihara dengan baik. Slametan desa (bacaslametan deso) atau dalam bahasa lokal sedekah desa yang selalu diadakan setiap tahun sekali pada seluruh pedesaaan dan kelurahan di komunitas Using cukup kuat disebut sebagai contoh untuk hal ini. Pada tradisi sedekah desa itu, masing-masing wilayah memiliki cara yang khas dalam tata cara pelaksanaannya. Desa Grogol kecamatan Giri misalnya, menyelenggarakan sedekah desa pada bulan Rajab dengan tontonan tradisional yang didahului dengan doa bersama di atas makam leluhur (Buyut Jiman). Di desa Boyolangu, yang leluhurnya bernama Buyut Jaksa, sedekah desa diadakan pada bulan Syura dengan ritual slametan di jalan utama desa tanpa diselingi tampilan seni budaya. Selain tradisi ritual, desa ini juga memiliki tradisi piknik kolosal yang disebut puter kayun yang dilaksanakan pada setiap tanggal 10 Syawal.

Sedikit berbeda dalam menghormati leluhur yang telah berjasa membuka lahan untuk pertanian dan permukiman adalah desa Bakungan, Kemiren, Olehsari, Alasmalang, dan Aliyan. Desa Alasmalang dan Aliyan, sedekah desa dilakukan dengan mengadakan atraksi kebo-keboan, yaitu beberapa orang dirias seperti kerbau untuk kemudian diarak mengelilingi desa dengan membawa uba rampe dari hasil pertanian. Arak-arakan juga dilakukan warga masyarakat Kemiren dalam tradisi sedekah desa, 
hanya saja di sini mereka berjalan mengelilingi desa mengiringi Barong. Adapun di Bakungan dan Olehsari, slametan itu dilakukan dengan menggelar atraksi seblang. Perbedaan di kedua desa ini hanya pada pelaku dan waktunya, kalau di Bakungan yang menjadi penari seblang adalah perempuan tua yang telah cukup umur, sementara di Olehsari adalah perempuan yang masih muda. Bahkan pada tahun 90-an, penari seblang di Olehsari ini harus seorang gadis yang belum pernah menikah. Perbedaan lain, di Bakungan hanya semalam pada bulan Dzulhijjah, sedang di Olehsari selama tujuh hari berturut pada bulan Syawal, biasanya beberapa hari setelah hari Raya Idul Fitri. Seluruh ritual budaya ini selain sebagai wujud ekpresi keberagamaan juga menandakan dekatnya masyarakat dengan alam kehidupannya.

Pelaksanaan sedekah desa di masyarakat Using di atas, selalu diadakan ritual keliling desa yang disebut dengan ider bumi. Kata ider artinya keliling, sehingga ider bumi ini berarti mengelilingi tanah atau area tempat tinggal mereka, yaitu perkampungan penduduk. Ider bumi di desa Kemiren dilakukan dengan arak-arakan kesenian barong pada setiap tanggal 2 Syawal. Di tengah perjalanan rombongan berhenti sejenak tepat di dekat makam Buyut Cili yang menurut sesepuh desa adalah luluhur masyarakat Kemiren. Wujud kegiatan dengan kesenian Barong itu juga merupakan pesan dari $S i$ Buyut dan kini telah menjadi mitos yang (harus) dipatuhi bersama, sehingga warga masyarakat tidak diperkenankan merubah apalagi meninggalkannya. Serupa dengan di Kemiren, di desa Olehsari ider bumi dilakukan mengiringi penari seblang yang intrance sambil berjalan berkeliling desa. Arak-arakan seblang berhenti sejenak di dekat makam Buyut Bisu (leluhur masyarakat) untuk memberi hormat kepadanya. Setelah menunjukkan tanda bekti dengan ritual tanpa gerakan apa-apa, rombongan kemudian melanjutkan perjalanan menuju balai desa tempat penutupan acara sedekah desa.

Di tempat yang lain, yaitu di sebagian besar desa di wilayah yang masuk dalam kategori wilayah masyarakat Using, ider bumi dilakukan dengan melantunkan kalimah thayyibah selama perjalanan mengelilingi desa. Kemudian lantunan kalimah thoyyibah itu berhenti berganti dengan kumandang adzan pada setiap sudut jalan. Warga masyarakat pria yang bergabung dalam acara ider bumi berhenti di sudut jalan, kemudian mereka menghadap ke arah kiblat untuk bersama-sama mengumandangkan adzan dan setelah berdoa untuk keselamatan desa dan para penghuninya, perjalanan dilanjutkan meskipun dinamakan sedekah desa, pada dasarnya bukanlah desa secara administratif, tapi hanya dusun atau kampung (pemukiman). Karena itu, setiap dusun pada desa yang sama memiliki waktu dan cara tersendiri dalam pelaksanaan acara 
sedekah desa ini. Demikian juga, ider bumi tidak selalu dilaksanakan, meskipun dusun tersebut tidak meninggalkan ritual yang dinamakan sedekah desa ini.

Makalah ini akan difokuskan pada pembahasan mengenai sedekah desa yang mewujud dalam tradisi ritual unik yang telah menjadi komoditas budaya masyarakat Banyuwangi, yaitu keboan di desa Aliyan dan kebo-keboan di desa Alasmalang. Nama kedua kegiatan ritual tradisional ini hampir sama, yaitu keboan dan kebo-keboan, sementara bentuk pelaksanaan dan tujuan dilakukannya sama persis, demikian juga waktunya, hanya beda hari pada bulan yang sama, bulan Syura dalam kalender Jawa. Karena kesurupan itu, penulis hanya melakukan penelitian lapangan di desa Alasmalang. Sementara untuk informan yang berhubungan dengan sedekah desa yang dilakukan oleh masyarakat Using dan kekhasan ider bumi diambil dari berbagai kalangan; ada kyai atau ulama dan reprentasi keduanya seperti guru ngaji atau ustadz, budayawan atau pengamat budaya, masyarakat umum dan simpatisan. Tidak ketinggalan praktisinya sebagai elemen yang sangat vital, yaitu para pelaku langsung yang terdiri dari pawang dan orang-orang yang berperan sebagai kerbau.

Penelitian budaya dengan mengambil tema "Islam dan Kebijaksanaan Lokal (Local Wisdom)" ini dilakukan di desa Alasmalang kecamatan Singojuruh. Orbitasi desa ini pada km-19 dari pusat pemerintahan kota. Desa ini masuk dalam wilayah kecamatan Singojuruh dan dari kantor kecamatan hanya berjarak $5 \mathrm{~km}$. Di samping membahas kebo-keboan yang menjadi tradisi tahunan masyarakat Alasmalang dan kebanggaan masyarakat Banyuwangi, penulis juga akan mengungkap falsafah yang ada di balik tradisi masyarakat Using yang lain, yaitu ider bumi. Ketertarikan penulis pada fenomena kebo-keboan dan ider bumi ini karena keduanya inheren dalam diri penulis. Sebagai bagian dari tradisi tersebut, dari sudut tourisme, penulis merasa berkewajiban mempromosikannya ke khalayak agar semakin kondang. Sementara dari sudut intern keagamaan, agar tidak muncul tuduhan musyrik terhadap penulis yang simpati dan terhadap orang-orang muslim lain yang memiliki sensitivitas budaya yang sama.

Kebo-keboan di Alasmalang dan ritual ider bumi di hampir keseluruhan masyarakat Using mengandung spirit religius yang khas, karena pada dasarnya adalah upaya sosial dan doa (ritual) untuk memohon kepada Tuhan Yang Maha Kuasa bagi kesejahteraan dan keselamatan hidup masyarakat. Kondisi yang demikian itu, pada masyarakat agraris terwujud di antaranya pada kesuburan tanah, panenan yang melimpah, dan terhindar dari segala macam malapetaka. Pembahasan pada makalah ini akan diawali dengan tradisi kebo-keboan dan fungsinya menurut kepercayaan 
masyarakat setempat serta nilai yang bisa diambil sebagai ritual maupun atraksi budaya. Sebelum mengakhiri dengan penutup, penulis akan membahas ider bumi dan nilai yang terkandung dengan tafsiran filosofis dan kultural yang selanjutnya akan diakhiri dengan simpulan dan rekomendasi kultural pada bagian penutup.

\section{Nilai yang Terkandung di dalam Kebo-keboan}

Mengawali penelitian untuk keperluan tulisan ini, penulis menemui seorang tokoh agama setempat. Ketika ditanyakan perihal tradisi masyarakat yang bagi kalangan tertentu dianggap mengandung unsur kemusyrikan ini, Ustadz tersebut menjawab dengan memberi ilustrasi yang menarik :

"Seandainya ketika sedang lewat di sebuah jalan, tiba-tiba saya dicegat (bahasa Using yang berarti dihadang) preman yang minta uang, saya akan memberinya sekedar yang saya mampu, mau, dan pantas. Itu saya lakukan demi untuk keselamatan saya dan orang yang bersama saya. Karena kalau tidak diberi, dia (si preman) pasti akan mengganggu perjalanan saya bahkan mungkin juga orang lain yang melalui jalan itu" (Warsito, wawancara: 9 Juli 2011).

Penjelasan Warsito di atas sekaligus menunjukkan sikapnya terhadap tradisi kebo-keboan yang dilakukan oleh masyarakat Alasmalang. Ia mengumpamakan ritual itu sebagai suatu permintaan yang harus dipenuhi oleh manusia sebagai persembahan kepada makhluk halus (jin). Bila hal itu tidak dilakukan, jin yang diumpamakan preman itu pasti mengganggu ketentraman masyarakat. Ia percaya jin itu ada dan di antara mereka membutuhkan santunan berupa persembahan kebo-keboan itu.

Di tempat yang lain, seorang tokoh agama (Subkhi, wawancara: 9 Juli 2011), menganggap tradisi kebo-keboan itu sebagai hal yang wajar untuk ekspresi kebudayaan. Memang dalam ritual tersebut ada beberapa orang yang masih percaya adanya kekuatan magic yang akan membantu untuk mengantarkan manusia pada tujuan yang diinginkan, tapi itu hanya sebagian kecil. Kebanyakan warga, yang terbilang kurang agamis sekalipun hanya menganggap sebagai kekayaan budaya yang perlu dilestarikan. Kalaupun ada orang yang percaya terhadap kekuatan makhluk halus yang mengiringi ritual tersebut tidak sampai mengantar mereka kepada syirik. Apalagi al Quran, sebagai pegangan pokok orang Islam juga sudah menyebut eksistensi makhluk halus yang disebut jin tersebut (QS al Jinn: 1-2). Oleh karena itu, tokoh ini tetap merekomendasikan agar acara tersebut dilestarikan, sementara keyakinan masyarakat terhadap adanya kekuatan magic tidak perlu ditentang secara frontal, tapi cukup dengan dibina dan ia yakin kelak akan hilang seiring dengan perkembangan pendidikan dan pengetahuannya. 
Ritual kebo-keboan digelar setahun sekali pada bulan Muharram atau Syura (Kalender Jawa). Konon, ritual ini sudah ada sejak abad ke-18. Di Banyuwangi, kebokeboan dilestarikan di dua tempat yakni di desa Alasmalang, kecamatan Singojuruh, dan desa Aliyan, kecamatan Rogojampi (Hasan Bashri, wawancara: 17 Juli 2011). Munculnya ritual kebo-keboan di desa Alasmalang berawal dari terjadinya musibah pagebluk (epidemi). Kala itu, seluruh warga diserang penyakit, hama wereng juga menyerang tanaman petani. Banyak warga yang kelaparan dan mati akibat penyakit misterius itu. Dalam kondisi seperti itu, sesepuh desa yang bernama Buyut Karti melakukan meditasi di sebuah bukit dekat desa. Selama meditasi, tokoh ini mendapatkan wangsit (pesan spiritual) yang isinya meminta seluruh warga menggelar ritual kebo-keboan sebagai penghormatan kepada Dewi Sri, yaitu dewi yang dipercaya sebagai simbol kesuburan dan kemakmuran. Keajaiban muncul ketika warga menggelar ritual kebo-keboan, warga yang sakit mendadak sembuh dan hama yang menyerang tanaman padi sirna. Sejak itu, ritual kebo-keboan dilestarikan karena warga khawatir akan terkena musibah lagi jika tidak melaksanakannya (Awi, wawancara: 7 Juli 2011).

Prosesi upacara kebo-keboan di Alasmalang dilaksanakan setahun sekali, yaitu pada hari Minggu antara tanggal 1-10 Syura dengan tanpa melihat hari pasarannya (pon, wage, kliwon, legi, pahing). Dipilihnya hari Minggu dengan pertimbangan bahwa pada hari tersebut kebanyakan warga masyarakat libur, sehingga dapat mengikuti jalannya upacara yang selalu dihadiri warga luar desa ini, bahkan juga dari luar kota. Adapun dipilihnya bulan Syura dengan pertimbangan bahwa bulan tersebut menurut kepercayaan masyarakat Jawa adalah bulan yang keramat, di samping juga memang merupakan pesan Buyut Karti seminggu sebelum pelaksanaan acara, warga yang berada di dusun Krajan mengadakan kegiatan gotong-royong untuk membersihkan lingkungan rumah dan dusunnya.

Selanjutnya, satu hari menjelang pelaksanaan acara, ibu-ibu mempersiapkan sesajen yang terdiri dari tumpeng, peras, air kendi, kinang ayu, aneka jenang, inkung ayam dan lain sebagainya. Selain itu, dipersiapkan pula berbagai perlengkapan upacara seperti para bungkil, singkal (alat bajak tradisional), pacul (cangkul), peras pitung tawar, beras, pisang, kelapa dan bibit tanaman padi. Seluruh sesajen tersebut selain untuk acara slametan, nantinya juga akan ditempatkan di setiap perempatan jalan yang ada di dusun Krajan. Pada malam harinya, para pemuda menyiapkan berbagai macam hasil tanaman palawija seperti pisang, tebu, ketela pohon, jagung, pala gantung, pala pendhem, dan pala kesimpar. Tanaman tersebut kemudian ditanam kembali di sepanjang jalan dusun 
Krajan. Selain itu, mereka mempersiapkan pula genangan air mirip bendungan yang nantinya akan digunakan untuk mengairi tanaman palawija yang telah ditanam itu.

Pada pagi hari pelaksanaan acara, sekitar pukul 08.00 WIB, diadakan slametan di Petaunan yang dihadiri oleh panitia, sesepuh dusun, modin, dan beberapa warga masyarakat sekitarnya. Pelaksanaan acara slametan di tempat ini berlangsung cukup sederhana, hanya berupa sambutan dari pihak panitia, kemudian dilanjutkan dengan doa secara islami yang dipimpin oleh modin dan diakhiri dengan makan bersama. Selanjutnya para peserta yang terdiri dari para sesepuh dusun, seorang pawang, perangkat dusun, tiga pasang kebo-keboan (dulu ada 15 pasang), para pembawa sesajen, pemain penabuh, pemain barongan dan warga dusun sekitar melakukan pawai ider bumi mengeliling dusun Krajan. Pawai ini dimulai dari Petaunan kemudian berjalan menuju ke genangan air sebagai tempat berkubang kerbau yang berada di ujung jalan dusun Krajan. Sesampai di genangan itu, jagatirta (petugas pengatur air) segera membuka penutup air agar mengalir ke sepanjang jalan dusun yang telah ditanami tadi.

Sementara air terus mengalir, para peserta upacara segera menuju ke areal persawahan milik warga dusun Krajan. Di persawahan inilah kebo-kebo tersebut mulai memperlihatkan perilakunya yang mirip kerbau yang sedang membajak atau berkubang di sawah. Pada saat kebo-kebo itu sedang berkubang, sebagian peserta segera turun ke sawah untuk menaburkan benih padi. Setelah benih ditaburkan, para peserta yang lain segera berebut untuk mengambil benih padi tersebut. Benih-benih itu dipercaya oleh sebagian warga masyarakat dapat dijadikan penolak bala, mendatangkan keberuntungan dan dapat membawa berkah. Pada saat para peserta memperebutkan benih itu, kebo-kebo jadian yang sebelumnya telah dibacakan mantra oleh pawang sehingga kepileng (trance, tidak sadar) itu akan mengejar para pengambil benih yang dianggap sebagai pengganggu. Namun demikian, kerbau-kerbau itu tidak sampai mencelakai para pengambil benih karena sang pawang selalu mengawasi setiap gerak-geriknya. Setelah dirasa cukup, sang pawang akan menyadarkan kembali kebo-kebo itu dengan cara mengusapkan air peras pitung tawar pada bagian kepalanya. Setelah itu, mereka kembali lagi ke Petaunan, tempat berakhirnya acara ritual kebo-keboan (Rahwat dkk, wawancara: 7-10 Juli 2011).

\section{Fungsi Kebo-Keboan bagi Masyarakat}

Sepanjang perjalanan sejarah, kehidupan seni sebagai bagian dari kebudayaan tidak pernah luput dari perubahan. Perubahan itu terjadi mungkin karena perkembangan pola pikir dan pemahaman manusia terhadap alam dan apa yang ada di sekitarnya, atau 
mungkin karena gesekan-gesekan dengan unsur lain yang ada di luar dirinya. Dengan demikian, tanpa adanya gangguan yang ditimbulkan oleh masuknya unsur budaya asing sekalipun, suatu kebudayaan dalam suatu masyarakat bisa berubah. Sejalan dengan bergulirnya waktu, senipun hanyut dalam pasang surutnya dinamika budaya (Ihromi, 1981: 32). Kesenian itu sendiri, dalam berbagai wujud pengekspresiannya, dapat dijadikan sebagai cermin budaya, karena ia selalu bergerak bersama dengan hati masyarakatnya. Jenis-jenis kesenian dalam konteks kemasyarakatan mempunyai kelompok-kelompok pendukung tertentu dengan fungsi yang berbeda-beda. Ada yang berfungsi hanya sebagai hiburan tanpa memiliki nilai religi, tetapi ada juga yang bernilai religi, dalam arti pelaksanaannya disertai dengan suatu keyakinan atau kepercayaan tertentu.

Kebo-keboan, sebagai aset budaya yang mengandung kebijaksanaan lokal (local wisdom) adalah salah satu contoh budaya yang dipercaya bernilai sakral di masyarakat Using Alasmalang. Dari tata cara pelaksanaan dan unsur tersirat yang memotivasi warga untuk menyelenggarakannya, tampak upacara ini merupakan warisan budaya HinduBudha. Salah satu cirinya adalah kepercayaan masyarakat kepada makhluk halus dan kekuatan supranatural untuk mengendalikan sesuatu dengan menggunakan sarana religi (Koentjaraningrat, 1984: 237). Upacara kebo-keboan bagi masyarakat Alasmalang merupakan sarana komunikasi dengan Tuhan maupun dengan leluhurnya. Dengan demikian, kesenian ini di samping membawakan pesan-pesan yang kaitannya dengan religi juga membawa pesan dalam tata hubungan sosial atau pergaulan antar sesama (Daeng, 2000: 81).

Setelah mengamati dengan teliti (deskripsi dari para pelaku dan menyaksikan video) dan mengadakan wawancara secara mendalam dengan warga sekitar, para pendukung maupun dengan para budayawan Using, serta mengamati lokasi dan jejakjejak pelaksanaan pada bulan Syura tahun lalu dari kegiatan ritual tahunan kebo-keboan ini, penulis ingin menjelaskan fungsi ritual ini bagi masyarakat pendukungnya. Fungsifungsi yang ada pada kebo-keboan menurut keyakinan warga dalam analisis penulis ada 4 (empat). Keempat fungsi tersebut adalah sebagai berikut:

Pertama, sebagai slametan bersih desa. Dalam bahasa Using orang juga biasa menyebut dengan sedekah desa. Dalam slametan bersih desa ini, seperti tercermin dari namanya, seluruh warga desa ikut terlibat. Bersih desa atau bersih dusun dilakukan sekali dalam setahun, yaitu pada bulan Syura atau Muharam dalam kalender Hijriyah. Slametan desa ini di samping sebagai tradisi yang telah populer di Tanah Jawa juga 
merupakan tradisi tahunan masyarakat Using yang masih terpelihara dengan baik. Pelaksanaannya di setiap desa bahkan dusun berbeda-beda. Meskipun namanya slametan desa, pada dasarnya hanya melibatkan warga dusun atau kampung tertentu. Dalam melakukan bersih desa, secara spiritual masyarakat membersihkan diri dari kejahatan, dosa, dan segala yang menyebabkan kesengsaraan. Hal ini tercermin dari berbagai aspek di beberapa perayaan serupa yang diselenggarakan masyarakat Using, seperti seblang di Olehsari dan Bakungan, atau barong ider bumi di Kemiren. Di samping itu, upacara-upacara tersebut juga menandakan adanya sisa-sisa adat penghormatan terhadap roh nenek moyang (Koentjaraningrat, 1984: 374).

Tradisi upacara bersih desa dalam masyarakat Jawa merupakan upacara yang sangat penting dan bersifat keramat. Upacara keramat seringkali mempunyai prosesi yang tidak sederhana dan tentu saja membutuhkan biaya yang lebih besar daripada upacara slametan biasa di dalam kehidupan masyarakat desa. Upacara kebo-keboan di Alasmalang diyakini masyarakat sebagai upacara yang keramat. Hal ini bisa diamati dari proses awal dalam penentuan segala sesuatu yang berkaitan dengan tempat, pelaku dan prasarana upacara. Masyarakat Alasmalang mengadakan upacara bersih desa bertujuan agar seisi desa dijauhkan dari berbagai petaka yang mengancam ketenangan dan keamanan mereka. Mereka mengharapkan agar diberi berkah, keselamatan, kesuburan tanah dan hasil panenan atau usaha yang baik, dijauhkan dari hama, dari berbagai penyakit, kerusuhan dan berbagai macam harapan baik lainnya untuk kehidupannya. Harapan serupa ada pada semua tradisi slametan desa di masyarakat Using Banyuwangi, seperti telah disebutkan di atas.

Dalam kepercayaan masyarakat, upacara ritual ini diselenggarakan bertujuan untuk membersihkan desa dari sesuatu yang tidak kasat mata (gangguan makhluk halus) dan dari gangguan yang disebabkan oleh ulah manusia. Gangguan yang disebabkan oleh manusia berupa perusakan lingkungan maupun pencurian dan kejahatan lainnya. Lebih jauh, mereka menyakini bahwa apabila upacara selalu dilakukan setiap tahun, tentu halhal seperti perusakan lingkungan dan kejahatan-kejahatan lainnya tidak akan terjadi. Namun sebaliknya, jika upacara tidak diselenggarakan keseimbangan alam dan lingkungan akan terganggu (Rahwat dkk, wawancara: 9 Juli 2011).

Kedua, sebagai pengundang kesuburan. Budaya agraris atau segala kehidupan yang mengandalkan keberuntungan dari hasil alam masih sangat mewarnai kehidupan masyarakat Alasmalang. Dalam masalah pertanian, mereka masih sangat kuat dengan pola bercocok tanam secara tradisional. Artinya, pola-pola penanaman, pemeliharaan, 
sampai pengolahan tanah dan peralatan yang dipergunakan masih mempergunakan alat dan sistem tradisional, seperti untuk membajak sawah tenaga sapi dan kerbau masih memegang peranan penting. Begitu juga ketika panenan, ekrak (alat penuai) dan arit (sabit) masih dominan. Meskipun upacara ini telah dikemas dalam bungkus budaya yang layak jual dari sudut touristme, ruh agraris yang memotivasi warga masyarakat masih sangat kentara (Kusmiyati, 2000: 41).

Dalam kehidupan yang tergantung dari hasil tanaman yang dilatarbelakangi pola pikir yang relatif sederhana itu, mereka tidak bisa lepas dari alam lingkunganya. Ketergantungan terhadap alam atau hukum-hukum alam seperti musim kemarau atau penghujan menentukan kehidupan sehari-hari. Selain itu, masyarakat petani pada umumnya dan petani Alasmalang khususnya, sangat percaya adanya kekuatan-kekuatan alam atau gaib yang dapat mempengaruhi lingkungannya. Sehubungan dengan itu, wajar jika masyarakat mendambakan kesuburan dalam pertanian maupun ketentraman dan ketenangan di bidang yang lainnya. Untuk mencapai kesuburan tersebut, masyarakat petani tradisional di Alasmalang mengusahakan dengan penuh ketekunan, baik yang berhubungan dengan dunia rasional maupun kepercayaan. Usaha yang secara rasional telah mereka lakukan dalam kegiatan sehari-hari, sedangkan yang bersifat kepercayaan dilakukan pada waktu tertentu, di antaranya dengan slametan desa ini

Salah satu slametan kolosal yang telah mengakar sejak dulu sampai sekarang pada masyarakat Alasmalang ini adalah upacara kebo-keboan. Dengan melaksanakan ritual ini, harapan mengenai kesuburan diungkapkan lewat simbol-simbol atau barang perlengkapan yang menjadi uba rampe pelaksanaan upacara. Benda-benda itu diwujudkan dengan sesaji berupa para bungkil yang digantungkan di perlengkapan upacara selama acara berlangsung. Simbol atau benda-benda para bungkil terdiri dari berbagai jenis tanaman, buah-buahan, bunga-bungaan, sayur-mayur dan lain sebagainya. Melalui representasi hasil pertanian dengan sajian para bungkil itu, masyarakat berharap agar yang ditanam menjadi subur, aman dari hama dan bisa memetik hasilnya dengan melimpah, sehingga bisa mencukupi kebutuhan hidup seharihari.

Ketiga, upacara kebo-keboan merupakan penghormatan kepada leluhur. Upacara kebo-keboan yang penuh dengan nuansa magic merupakan perwujudan atau realisasi penghormatan masyarakat kepada roh leluhurnya. Perwujudan ini dapat dilihat pada sajian tarian kerbau jadi-jadian itu di samping juga dari mantra yang diucapkan sang dukun. Dukun atau pawang yang selalu mendamping pelaksanaan upacara sejak 
beberapa tahun yang lalu sampai sekarang adalah Bapak Rahwat yang tinggalnya $50 \mathrm{~m}$ sebelah utara masjid Krajan. Dalam kepercayaan masyarakat, leluhur dan keturunannya masih bisa memberi pengaruh bahkan juga menyaksikan apa yang masyarakat lakukan terhadap dirinya saat ini (Zaehner, 2004:111). Dengan demikian dapat dipahami ritual ini berfungsi sebagai sarana pengekpresian rasa hormat masyarakat kepada leluhurnya. Uraian di atas juga dijelaskan oleh Murgiyanto dan Munardi sebagai berikut:

Masyarakat sangat menghormati roh cikal bakal, dan menganggap roh itu masih berpengaruh terhadap desanya. Segala peristiwa yang menyangkut perkembangan serta perubahan-perubahan di desa tersebut harus selalu mendapatkan perkenan atau diketahui oleh sang cikal bakal. Kelalaian penghoramatan kepadanya dapat mengganggu kesejahteraan dan kedamaiaan masyarakat yang bersangkutan (Murgiyanto dkk, 1990: 16).

Memang dalam kepercayaan masyarakat Using, ada anggapan bahwa orang yang telah meninggal rohnya masih hidup bersama dengan anak cucunya yang masih hidup. Roh nenek moyang itu akan jangkungi, artinya merestui anak cucunya manakala mereka mematuhi perintah dan petunjuk-petunjuk yang diberikan Sebaliknya, roh-roh tersebut akan marah jika mereka tidak mematuhi dan enggan menjalankan apa yang di anjurkan.

Keempat, sebagai hiburan roh halus. Sebelum terjun ke lapangan untuk melakukan wawancara dengan para pelaku dan warga sekitar lokasi dilaksanakannya upacara kebo-keboan, penulis bersilaturrahim kepada seorang tokoh agama di Banyuwangi. Di situ penulis mengutarakan beberapa fenomena kebudayaan Using yang diikuti keyakinan tertentu (magic) oleh sebagian warga masyarakat sekitarnya, seperti seblang di Olehsari dan Bakungan, demikian juga kebo-keboan ini. Baginya, tradisi ini telah menjadi komoditas budaya yang juga memiliki manfaat sosial, seperti kerukunan, gotong-royong dan juga ekonomi. Oleh karena itu, tidak perlu dihapus tapi perlu diluruskan agar tidak menggiring kepada keyakinan yang lebih keliru (syirik).

Tokoh ini percaya bahwa tradisi-tradisi tersebut menjadi kekuatan sosial budaya yang telah menjadi milik bersama masyarakat (publik). Sebagai bagian dari masyarakat, ia mendukung pelaksanaan acara tersebut, meskipun ia merasa berkewajiban menghapus kepercayaan yang mengiringinya. Ia yakin suatu saat kepercayaan itu akan hilang seiring dengan meningkatnya kualitas sumber daya manusia dan pendidikan keagamaan masyarakat (Shodiq, wawancara: 5 Juli 2011). Secara sosiologis, pemahaman keagamaan masyarakat yang homogen (satu agama) memang berbeda dengan pemahaman keagamaan masyarakat yang heterogen (multi agama). Demikian 
pula di Alasmalang ini dan tempat lain yang memiliki tradisi serupa, keislaman orang yang di lokasi tersebut harus dipahami dalam perspektif yang berbeda dengan keislaman masyarakat di tempat lain yang homogen (Askari, 2003: 11).

Pada sisi yang lain, sebagian pendukung setia upacara kebo-keboan mengemukakan bahwa ritual itu selain disaksikan oleh manusia biasa juga dihadiri oleh manusia halus (dirawuhi tiyang alus). Tiyang alus tersebut menurut mereka adalah leluhur masyarakat dan yang mbaureksa desa serta roh cikal bakal. Mereka itu di antaranya bernama Mbah Suma dari Singojuruh, Mbah Belanggur dari Serawed, Mbah Tanjung dari Puger Jember, dan Sayu Nirwati serta Buyut Karti sendiri (Rahwat, wawancara: 7 Juli 2011). Penjelasan ini memang tidak masuk akal dan sulit untuk dibuktikan kebenarannya. Namun jika kita telusuri tentang fungsi ritual di pulau Bali, masyarakatnya juga mempercayai bahwa kelompok tari Bebali yang dipentaskan di Pura Jaba Tengah difungsikan untuk menghibur para dewa yang hadir dan tamu terkemuka. Selain itu, kategori genre seni pertunjukan yang sakral yaitu wali, disajikan khusus untuk persembahan para dewa. Salah satu contoh tarian itu adalah tari Rejang. Tarian ini merupakan bagian dari prosesi memandikan patung kayu (pratima) ketika dewa-dewa datang dan bersemayam di dalam pratima tersebut. Kemudian para penari menyajikan tari Rejang untuk menghibur para dewa yang hadir di tempat itu (Subagyo, 1998: 133)

Kepercayaan serupa juga dijumpai pada tradisi kraton Yogyakarta dengan tarian Budaya Semang-nya. Tarian ini sebagai simbol kekeramatan hubungan gaib antara Sultan Agung (perintis Dinasti Mataram) dengan Kanjeng Ratu Kidul. Ketika tari diperagakan diyakini Ratu hadir dan menyaksikannya. Bahkan di masa sekarang, di era yang modern dan rasional ini, masih ada yang mengira hubungan itu tetap terjalin antara keturunan Kanjeng Sultan dengan Ratu Rara Kidul. Karena itu, tari Budaya Semang juga tetap lestari (guide mantan prajurit Kraton Ngayogyakarta, wawancara 29 Juni 2011). Dengan demikian tarian dan ritual tersebut, termasuk kebo-keboan di Alasmalang ini tampaknya memang ditujukan untuk menghibur "sesuatu" yang tidak kasat mata (Suyono, 2007: 107-109).

\section{Nilai Sosial Budaya Kebo-keboan}

Upacara kebo-keboan di desa Alasmalang, tepatnya di dusun Krajan, jika dicermati secara mendalam, mengandung nilai-nilai yang pada gilirannya dapat dijadikan acuan dalam tata-hidup kemasyarakatan sehari-hari. Nilai-nilai itu, dalam pandangan 
penulis ada tiga hal, yaitu kerukunan, ketelitian, dan religius atau keagamaan. Nilai kerukunan atau kebersamaan tercermin dari berkumpulnya sebagian besar anggota masyarakat dalam suatu tempat untuk bergotong-royong mempersiapkan berbagai hal yang berhubungan dengan pelaksanaan acara tersebut. Dalam kegiatan itu, mereka makan bersama dan berdoa bersama demi keselamatan bersama pula. Ini adalah wujud kerukunan dan kebersamaan yang merupakan cerminan dari tepaslira dan toleransi dalam kehidupan bermasyarakat. Dalam arti yang lebih luas, ini juga menunjukkan kemenyatuan mereka sebagai wujud rasa memiliki terhadap lingkungan dan kehidupan sekitarnya. Oleh karena itu, upacara ini jelas bermanfaat secara sosial bahkan juga memiliki nilai ekonomi bagi masyarakat sekitarnya. Dengan ungkapan lain, upacara ini merupakan ekspresi kerukunan dan kebersamaan sebagai komunitas yang memiliki wilayah, adat-istiadat dan tradisi berkebudayaan yang sama.

Adapun nilai ketelitian tercermin dari proses upacara itu sendiri yang membutuhkan energi ekstra. Sebagai suatu kegiatan kolosal, upacara kebo-keboan memerlukan persiapan tertentu yang berhubungan dengan perlengkapan sebelum acara, pada saat prosesi, maupun setelah usai kegiatannya. Persiapan-persiapan itu tidak hanya menyangkut peralatan upacara, tetapi juga tempat, waktu yang tepat, pemimpin spiritual yang akan bertugas mengkondisikan psikologi para pelaku dan peserta yang akan mengiringi perjalanan mengelilingi kampung. Kesemuanya itu harus dipersiapkan dengan baik dan seksama, agar pelaksanaan acara berjalan lancar tanpa halangan yang berarti. Untuk itu dibutuhkan ketelitian dan kecermatan yang berarti merupakan kerja fisik dan psikis sekaligus.

Sementara itu, nilai keagamaan tercermin dari kesadaran bahwa sukses tidaknya pelaksanaan upara tersebut bukan semata bergantung pada kesiapan secara fisik dan mental yang berdiri sendiri tanpa keterikatan dengan faktor di luar diri manusia. Faktor yang ada di luar diri manusia itu adalah kekuatan alam yang dikendalikan Tuhan Yang Maha Esa sebagai pusat yang paling sentral dari semua aktivitas ini. Agama bukanlah terbatas hanya pada kegiatan ritual saja, tapi menyangkut kesadaran supranatural pada entitas yang ada di alam ini. Agama, memang sudah sejak lama diketahui tidak bisa dilacak sepenuhnya dari pengetahuan rasional, karena Tuhan yang diimani sebagai penuntun kepada kebenaran itu memang Misteri yang Maha Ghaib, bisa dibicarakan, didiskusikan, digambarkan dengan analogi yang macam-macam, namun tidak dapat ditangkap mata atau panca indra lainnya (Khakim, 2007: 71). 
Agama juga tidak bisa dilacak dari tindakan moral saja, karena ia menuntut niat sebagai basis amal para penganutnya. Oleh karena itu, tidak sedikit ilmuan yang mencoba melihatnya secara fenomenologis, agama berasal dari perasaan kebergantungan mutlak kepada Yang Tak Terhingga (feeling of absolute dependence) kata Friederich Schleirmacher. Agama sebagai pengalaman pertemuan dengan Yang menimbulkan rasa ngeri dan cinta, sebuah misteri yang menakutkan dan sekaligus mempesona, kata Rudolf Otto. Konsep ini, sebuah misteri yang menakutkan dan mempesona kemudian diberi pengertian baru oleh Mircea Eliade dengan konsep "Yang Sakral" the sacred. Bagi Eliade pada setiap kebudayaan selalu dikenal adanya sense of sacred yang tercermin dalam ritus dan simbolnya. Inilah esensi dari agama menurut para sosiolog (Rahmat, 2005: 22).

Secara historis, sebelum mengenal ajaran agama, masyarakat Indonesia telah memiliki keyakinan yang disebut oleh Agus Sunyoto dengan istilah Kapitayan. Kapitayan dapat digambarkan sebagai suatu ajaran keyakinan yang memuja sembahan utama yang disebut Sangyang Taya, yang bermakna hampa. kosong, suwung, atau Awang-uwung. Taya bermakna Yang Absolut, yang tidak bisa dipikir dan dibayangbayangkan. Tidak bisa didekati dengan panca indera. Orang Jawa kuno mendefinisikan Sangyang Taya dalam satu kalimat "tan kena kinaya ngapa", yang bermakna tidak bisa diapa-apakan keberadaannya (Sunyoto, 2011:11)

Pada upacara kebo-keboan ini, nilai keagamaan yang sekaligus mengandung pendidikan kesadaran moral untuk menghargai sesama, alam lingkungan sekitar, dan terlebih Tuhan tampak pada puja mantra (doa islami) yang diucapkan Mbah Rahwat berikut :

"Allahumma Thaif Susut ket ana lintang sepuluh mendung teja mutung mega langit bumi Po lan kembang lintang jinjitan ingkang den dejelaken srengenge barang-barang, barang mbuh ghaib, barang kecekel sing kesurupan, sing kelangkaan, sing kaidekan, sing ngagem sarine wenang, wenang-wenang sangking kersaning Allah Ta'ala " (Rahwat, wawancara: 7 Juli 2011)

Fenomena kebo-keboan adalah pesta budaya yang bernuansa ritual. Meskipun berangkat dari mitos atau keyakinan yang sangat subjektif dan personal, ia telah menjadi milik publik dengan kaitan yang berbeda-beda antara satu orang dengan lainnya secara psikologis. Dalam kenyataan sosial yang demikian, siapapun bisa membangun mitos (nilai) baru yang lebih rasional dan berdasar ajaran atau nilai agama tertentu sesuai keyakinan personal untuk kebaikan bersama (kemaslahatan), tanpa harus menghapus 
aset budaya nusantara yang telah jelas membawa manfaat sosial-budaya dan ekonomi ini (Hidayat, 2003: 9)

\section{Ider Bumi dalam Konstruksi Keberagamaan Masyarakat Using}

Ungkapan Jawa yang menjadi dasar atau falsafah hidup orang Jawa yaitu: sepi ing pamrih, rame ing gawe, lan memayu hayuning bawana, dijelaskan oleh H.A. Shodiq sebagai berikut, bahwa segala aktivitas harus didasarkan kepada tuntutan kehidupan yang sejati tanpa tujuan duniawi. Kemudian dalam bekerja atau beraktivitas memenuhi tuntutan hidup ini orang harus energik untuk mengisi kehidupan ini dengan perbuatan yang berguna, baik bagi dirinya maupun bagi orang lain. Setelah itu, tindakan dan perbuatan harus diorientasikan untuk memperindah dunia atau kehidupan ini. Dunia yang indah itu di antaranya ada pada situasi dan kondisi hidup yang dilingkupi oleh kerukunan dan kebersamaan dalam situasi yang aman dan tentram. Dalam bekerja untuk memenuhi tuntutan kehidupan ini, manusia tidak diperkenankan melakukan tindakan sewenang-wenang terhadap orang lain dan bertindak ekploratif terhadap sumber daya alam (Shodiq, wawancara: 23 Juli 2011).

Dalam menjalani proses kehidupan ini, orang Jawa bisa melakukan beberapa hal untuk menggali makna hidup dari nilai-nilai kreatif, yaitu bekerja, berkarya dan melakukan sesuatu yang bermanfaat dengan penuh dedikasi. Penghayatan, yaitu menjalani proses kehidupan dalam bingkai keyakinan terhadap kebenaran suatu ajaran tertentu, dan senantiasa bersikap dan bertindak dengan baik dan tepat. Baik dan tepat bukan dalam ukuran normatif dengan ketentuan hukum yang rigid antara benar dan salah saja, tapi dengan perhitungan yang bijaksana sebagai cerminan ketinggian moral demi untuk tujuan yang lebih dari sekedar perhitungan untung dan rugi. Demi untuk kebaikan atau kemaslahatan bersama, orang Jawa mampu menahan diri, meskipun dengan sikap demikian tidak jarang membawa petaka (susah) bagi dirinya sendiri. Oleh karena itu, orang dituntut terus belajar untuk mengerti makna hidup, setahap demi setahap, setingkat demi tingkat. Dalam belajar itupun tidak baik nggege mangsa, tergesa-gesa tanpa mempertimbangkan kadar kemampuan yang dimiliki (Suseno, 2003: 121-122). Bila hal ini tidak diperhatikan, akan menimbulkan sesuatu yang tidak baik bagi diri si pelaku maupun bagi orang lain. Dalam ungkapan lain, ada peringkatperingkat tertentu dalam upaya memberi pemahaman mengenai makna hidup.

Pemeringkatan dalam menyampaikan ajaran moral (makna hidup) yang terjadi pada tradisi Jawa itu tampak dalam lagu-lagu Jawa, misalnya ada gendhing yang 
bernama mijil, sinom, maskumambang, kinanthi, asmaradhana, hingga megatruh dan pucung. Ternyata, kesemua jenis gendhing itu merupakan perjalanan hidup seorang manusia. Mijil, yang berarti keluar, dapat diartikan sebagai lahirnya seorang jabang bayi dari rahim ibu, sinom dapat di artikan sebagai seorang anak muda yang bersemangat untuk belajar, maskumambang berarti seorang pria dewasa yang cukup umur untuk menikah, sedangkan untuk putrinya dengan gendhing kinanthi. Proses berikutnya adalah pernikahan atau katresnan antara keduanya yang disimbolkan dengan Asmaradhana. Hingga akhirnya megatruh, atau dapat dipisah megat ruh. Secara semantik, megat berarti cerai atau pisah, sedangkan ruh adalah roh atau jiwa. Peristiwa pisahnya raga dengan jiwa merupakan proses sakaratul maut seorang anak manusia. Dalam tradisi masyarakat Islam di Jawa, prosesi penguburan jenazah (badan yang telah ditinggal ruh) biasanya dikafani (dibungkus) dengan kain kafan berwarna putih, inilah yang dinamakan dengan pocong atau pucung (Anshoriy dkk, 2008: 78-81). Kesemua jenis gendhing ini ditata apik dengan syai-syair yang beragam, sehingga mudah dipahami dan selalu kontekstual.

Alam seisinya ini juga tempat belajar ilmu atau kebijaksanaan. Seperti gendhing, alam ini juga mendendangkan syair lagu yang berisi ajaran moral. Kalaupun tidak mengerti dan tidak memahami yang tersirat dari syair alam, orang pasti tahu fungsinya yang kentara sebagai sumber kehidupan. Tanah misalnya, adalah sumber kehidupan. Tanpa tanah, tiada tempat makhluk berpijak. Di atas tanah manusia mendirikan bangunan rumah sebagai tempat tinggal. Di tanah manusia bercocok tanam padi, palawija, sayur-sayuran, buah-buahan, yang semuanya dikonsumsi oleh manusia untuk ketahanan fisik bahkan mentalnya. Tanah yang subur menjadi tempat yang nyaman bagi tanaman untuk tumbuh dan berkembang dengan baik. Demikian juga, tanah atau bumi yang aman, menjadi tempat tinggal yang menentramkan bagi manusia.

Di bumi juga ditemukan bermacam barang tambang, seperti emas, perak, biji besi, batu bara, gas, minyak bumi, dan lain sebagainya. Segala macam yang dikeluarkan bumi memberi manfaat bagi manusia, tidak hanya tumbuh-tumbuhan, bermacam hewan juga hidup di bumi dan bergantung dari tanah. Cacing tanah misalnya, meski tanpa indra yang sempurna, ia leluasa dan nyaman hidup di dalam tanah, karena memang di sanalah habitatnya. Begitupun semut dan sejumlah hewan lainnya yang berkembang biak dan bergantung hidupnya pada tanah. Namun demikian, terkadang tanah juga membawa bencana, misalnya tanah longsor. Oleh karena itu, manusia juga harus 
waspada dengan tanah-tanah tertentu, misalnya pinggir tebing, di kaki bukit yang rawan, maupun di tanah-tanah ketinggian yang berpotensi terjadinya longsor.

Tempat tinggal yang berdiri di atas tanah, rumah sebagai tempat istirahat dan berkumpul keluarga, dalam kebudayaan Jawa juga dipandang sebagai sesuatu yang sangat vital. Oleh karena itu, segala sesuatu yang berkenaan dengan perwujudan rumah senantiasa dirancang dan diperlakukan dengan menggunakan aturan atau pedoman tertentu yang mencerminkan pandangan falsafah Jawa. Bahkan di kalangan masyarakat Jawa terdapat ungkapan lain yang mencerminkan kelengkapan kesempurnaan hidup bagi lelaki Jawa, yaitu bahwa seorang lelaki baru dianggap sempurna kalau sudah memiliki lima hal, yaitu wanodya (wanita atau istri), turongga (kuda) sebagai lambang kedudukan, curiga (keris) lambang keamanan lahir dan batin, kukila (burung) lambang kesenangan atau hiburan, dan wisma (rumah) yang dipandang sebagai keberhasilan seseorang. Kelima hal ini, sekaligus menjadi lambang kebanggaan, kehormatan, dan keberhasilan. Menurut tata cara tradisional Jawa, ada anggapan bahwa antara rumah, tanah, dan manusia penghuninya merupakan suatu kesatuan yang tidak dapat dipisahkan. Orang merasa bersatu dengan rumah dan tanah tempat berdirinya, serta sekaligus merasa bersatu dengan desa tempat menetapnya. Perasaan kesatuan yang demikian ini menyebabkan rasa aman dan tenteram bagi para penghuninya (Santosa, wawancara: 24 Juli 2011).

Masyarakat Using yang tinggal di Banyuwangi mempunyai cara tersendiri untuk menghormati tanah dan segala yang menghuninya. Mereka mengadakan tradisi ider bumi dengan maksud mohon perlindungan kepada Tuhan bagi keselamatan masyarakat yang menghuni tanah yang ditinggali dan juga bagi yang ada di sekitar tempat huniannya. ider bumi yang dilakukan masyarakat Using di hampir setiap dusun di Banyuwangi ini sebenarnya hanya merupakan rangkaian dari upacara tahunan yang disebut slametan atau sedekah desa. Dalam acara slametan itu, hanya sebagian kecil yang masih tetap memelihara ritual magic warisan budaya leluhur. Di sebagian kecil dusun itu, pada bagian tertentu justru dikembangkan dengan alasan tertentu pula yang di antaranya meng-uri-uri tradisi sekaligus untuk menunjukkan kekhasan budaya Using. Kebo-keboan yang telah dibahas di atas adalah satu di antaranya, selain seblang dan barong ider bumi di Kemiren. Meskipun secara fisik tampak sebagai warisan budaya Animisme dan Hindu, namun semua pendukungnya adalah muslim, demikian juga niat dan doa yang mengiringi pelaksanaannya tidak ada lagi nuansa kehinduan. Oleh karena itu, kalangan ulama dan tokoh agama Islam tidak mempermasalahkannya untuk tetap 
dilestarikan. Apalagi upacara itu, dalam pandangan mereka memiliki kontribusi yang signifikan bagi pemberdayaan sosial ekonomi dan budaya warga sekitar.

Sementara itu, di masyarakat Using yang lain, slametan desa yang dilaksanakan setiap tahun sekali itu dilakukan sepenuhnya dengan cara-cara islami. Tahlil, sema'an (istima') al Quran, serakalan asyroqal (membaca barzanzi), dan istighasah (berdoa bersama-sama) dilakukan oleh dusun-dusun yang berada di desa Watukebo kecamatan Rogojampi. Dua dusun di desa ini, Glondong dan Gumukagung bahkan pada setiap bulan Rabiul Awwal (Maulid) mengadakan acara peringatan maulid nabi dengan besarbesaran. Acara peringatan maulid nabi yang dalam bahasa Using biasa disebut endogendogan yang dilakukan di kedua dusun ini seolah telah menjadi milik bersama masyarakat tanpa melihat latar belakang agama yang dianutnya. Pada acara endogendogan ini, warga Hindu yang tinggal di dusun Glondong bekerjasama dengan warga muslim mempersiapkan acara besar yang telah menjadi milik publik tersebut. Pada kegiatan seni budaya, penganut Islam dan Hindu juga bersatu dalam paguyuban Seni Janger yang diberi nama Darma Kencana (Supriyadi, wawancara: 13 Februari 2011)

Penyelenggaraan sedekah desa dengan acara islami juga dilakukan masyarakat Using yang lain, seperti Bulusari, Pesucen, Jambesari, Grogol, Boyolangu, Giri, Penataban, Labanasem dan Gendoh. Di beberapa dusun di desa-desa tersebut, selain melakukan kenduri (doa yang dilanjutkan makan bersama) juga dilakukan ritual mubeng kampung atau ider bumi (berkeliling dusun) dengan membaca kalimah thayyibah dan berhenti di setiap persimpangan jalan yang biasanya menjadi titik batas dusun untuk kemudian mengumandangkan adzan bersama-sama. Lazimnya beradzan, setelah itu mereka membaca doa yang biasa dibaca setelah adzan, kemudian dilanjutkan dengan permohonan untuk keamanan dan keselamatan desanya dari gangguan makhluk kasar dan makhluk halus (Suyono, 2007: 82-84). Waktu pelaksanaan ider bumi di setiap dusun di masyarakat Using itu berbeda-beda, namun biasanya pada bulan-bulan mulia, seperti Rajab dan Muharram.

Ider bumi yang dilakukan masyarakat Using di Banyuwangi di samping untuk memohon perlindungan kepada Tuhan bagi kehidupan masyarakat di bumi, juga merupakan penghormatan kepada segenap makhluk halus yang tidak mereka pungkiri keberadaannya (QS al Jinn:1-2). Secara spiritual, acara ini jelas fungsi dan manfaatnya bagi setiap individu penghuni desa tersebut, yaitu memperteguh dan mengontrol kondisi mental dan emosional warga. Sementara secara sosial, acara ider bumi itu juga mendatangkan manfaat yang signifikan bagi kehidupan masyarakat. Manfaat itu di 
antaranya ada pada perasaan semakin kuatnya tali ikatan kekeluargaan warga yang juga berimplikasi pada kerukunan dan keharmonisan masyarakat. Kerukunan dan keharmonisan itu pada dasarnya merupakan substansi dari semua ajaran agama, di samping keyakinan terhadap eksistensi Tuhan tentunya. Namun, sering pada tataran aplikasi substansi ajaran agama itu tertutup oleh kepentingan sesaat yang amat dangkal dan sangat duniawi sifatnya.

Acara sedekah desa ataupun acara lain yang telah menjadi miliki bersama warga desa, seperti seblang, barongan dan endog-endogan ternyata memang berdampak positif bagi warga. Hal itu tampak pada berkumpulnya seluruh warga dari berbagai kalangan, bahkan warga yang non-muslim sekalipun. Diungkapkan oleh Nengah Suwarko, bahwa kegiatan endog-endogan di dusun Glondong desa Watukebo bisa mempertemukan dan menyatukan warga yang setiap harinya disibukkan oleh pekerjaannya sendiri-sendiri. Berbagai warga kumpul dari berbagai kalangan dan keyakinan keagamaan. Pembiayaan kegiatan acara tersebut juga dilakukan. secara gotong royong dan ditanggung semua warga. Ia juga mengaku bahwa kegiatan tersebut juga menghadirkan nuansa toleransi yang kental. Dia memaklumi jika ada sejumlah warga yang keberatan dengan penyelenggaraan acara serupa, tapi keberatannya itu tidak sampai merintangi jalannya acara (Suwarko, wawancara: 17 Februari 2011)

\section{Simpulan}

Indonesia adalah bangsa besar dengan budaya yang beragam. Secara nasional, Indonesia memiliki dua macam sistem budaya, sistem budaya nasional dan etnik lokal. Sistem budaya nasional relatif baru dan masih terus dalam proses pembentukan. Sistem ini berlaku secara umum untuk seluruh bangsa Indonesia, tetapi sekaligus berada di luar ikatan budaya etnik lokal yang manapun. Nilai-nilai tersebut menjadi bercitra rasa Indonesia karena dipadu dengan nilai-nilai lain yang sesungguhnya diderivasi dari nilainilai budaya lama yang terdapat dalam berbagai sistem budaya lokal. Sistem budaya lokal, atau disebut juga kearifan lokal pada dasarnya merupakan landasan bagi pembentukan jatidiri bangsa secara nasional. Kearifan lokal itulah yang akan membuat suatu budaya bangsa memiliki akar kuat di masyarakat.

Kearifan lokal atau local wisdom lahir dari proses panjang yang dibimbing oleh nilai yang diyakini secara kolektif kebenarannya berupa kepercayaan atau agama. Kepercayaan itu kemudian, oleh watak omnipresent (hadir di mana-mana), ikut mempengaruhi bahkan membentuk struktur sosial, budaya, ekonomi dan juga politik. Di 
dalam sistem sosial budaya Alasmalang atau Using pada umumnya, kearifan itu menjelma dalam nilai dasar rukun yang menjadi falsafah hidup masyarakat. Nilai itu tidak diragukan berasal dari ajaran agama atau kepercayaan yang dianut masyarakat, di samping juga dari sistem etika sosial yang diwarisi secara turun temurun.

Kerukunan dan kebersamaan itu mewujud di antaranya dalam pelaksanaan upacara budaya kebo-keboan. Sebagai ritual budaya tahunan, tradisi ini sebenarnya tampak sebagai tradisi yang ambigu. Melihat tata fisik arena dan penyajian tari dengan segala asesoris yang menempel, juga sesaji yang dipasang di area pelaksanaan sebagai para bungkil dan suguhan, mirip dengan tradisi kasada yang dilaksanakan tahunan oleh suku Hindu Tengger, padahal pelaku dan penduduk sekitar memeluk agama Islam. Inilah manifestasi dari falsafah kerukunan yang menjadi inti dari tradisi dan budaya masyarakat Using Alasmalang di Banyuwangi. Prosesi budaya ini ditutup dengan upacara yang disebut ider bumi, yaitu seluruh masyarakat dipimpin oleh sesepuh desa mengelilingi perbatasan dusun dengan membaca doa secara islami sebagai permohonan keselamatan dan keamanan kepada Allah bagi kampung dan penghuninya.

Kegiatan lain yang selalu dilakukan masyarakat Using sebagai ritual sedekah desa tahunan setiap dusun adalah ider bumi. Di sebagian besar wilayah, acara ider bumi sudah tidak meninggalkan jejak budaya lama, namun masih kental dengan kekhasan Using-nya. Diawali dengan doa secara islami dari sebuah lokasi yang menjadi titik sentral aktivitas masyarakat, rombongan ider bumi berjalan mengelilingi kampung sambil melantunkan kalimah thayyibah. Kemudian mereka berhenti di persimpangan jalan untuk mengumandangkan adzan bersama-sama. Setelah adzan, mereka berdoa memohon keselamatan dan keamanan kampungnya dari segala gangguan dan bencana. Aktivitas tersebut dilakukan di setiap sudut kampung atau persimpangan jalan sampai di titik akhir, yaitu di balai desa. Di situ masyarakat kembali bersama dalam acara slametan atau kenduri.

Kebo-keboan dan ider bumi ini merupakan ekspresi budaya yang sekaligus harapan atau doa kepada Tuhan Yang Maha Esa. Dalam konteks demikian, keduanya tidak lain adalah sedekah desa atau slametan tahunan yang telah mengakar di masyarakat. Pemaknaan sederhana pada slametan di antaranya adalah agar wong nетио selamet dalam beraktivitas kerja, yang bertani tanamannya aman dan panenannya melimpah, yang berdagang sukses dan lancar dengan hasil yang memuaskan. Intinya segala jerih upaya untuk niat kebaikan mendapat perkenan Gusti Allah Yang Maha Kuasa. Di dalam slametan tersaji pecel pitik, yaitu ayam bakar yang dibumbu santan 
dengan menyertakan parudan kelapanya secara utuh yang disebut ampas. Dalam pemaknaannya, maksud disajikan pecel pitik adalah agar "kang diucel-ucel nemиo apik" yaitu semua yang dilakukan berakhir dengan mendapatkan kebaikan atau kemaslahatan.

Pemutlakan terhadap keyakinan keagamaan (truth claim), bagi masyarakat di suku Using ini hanya ada pada ruang personal di wilayah yang sangat private, sementara dari sisi sosial, mereka mengakui ruang dialogis yang penuh toleransi sebagai milik bersama. Ruang itu adalah kehidupan sosial kemanusian yang kini justru sering diabaikan oleh para penganut agama. Pada dasarnya, setiap agama memiliki visi kemanusiaan yang sama, bahwa setiap manusia merupakan makhluk suci yang harus dihormati. Oleh karena itu, sudah seharusnya pada aras kemanusiaan inilah, energi intelektual dan sosial umat beragama dikerahkan. Dengan begitu, selain agama akan terus menemukan signifikansi dalam realitas keumatan, ia juga akan menjadi rahmat bagi segenap alam. Hanya dengan bingkai keberagamaan yang inklusif dan humanis itulah tujuan agama diberikan (titipan) Tuhan ini bisa terwujud.

\section{Daftar Pustaka}

Anshoriy, H.M. Nasruddin dkk. 2008. Kearifan Lingkungan dalam Perspektif Budaya Jawa. Jakarta: Yayasan Obor Indonesia.

Askari, Hasan. 2003. Lintas Iman Dialog Spiritual. Terj. Sunarwoto. Yogyakarta: LkiS

Awi. 7 Juli 2011. Hasil Wawancara. Banyuwangi.

Beatty, Andrew. 2001. Variasi Agama di Jawa. Jakarta: Raja Grafindo Persada.

Daeng, Hans J. 2000. Manusia, Kebudayaan dan Lingkungan Tinjauan Antropologis. Yogyakarta: Pustaka Pelajar.

Guide Mantan Prajurit Kraton Ngayogyakarta. 29 Juni 2011. Hasil Wawancara. Banyuwangi.

Hidayat, Komaruddin. 2003. Budaya Lokal dalam Perspektif Baru : Dialektika Budaya dan Agama dalam Sinergi Agama dan Budaya Lokal. Surakarta: UNMU Press.

Hasan Bashri. 17 Juli 2011. Hasil Wawancara. Banyuwangi.

H. A. Shodiq. 5 juli 2011. Hasil Wawancara. Banyuwangi.

Ihromi. 1981. Pokok-pokok Antropologi Budaya. Jakarta. Gramedia.

Khakim, Indy G. 2007. Mutiara Kearifan Jawa. Yogyakarta: Pustaka Kaona.

Koentjaraningrat. 1984. Kebudayaan Jawa. Jakarta: Balai Pustaka.

Kusmiyati, A.M. Hermin. 2000. Arak-arakan dalam Seni Tradisional di Madura. Yogyakarta: Yayasan Untuk Indonesia. 
Murgiyanto, Sal dan Munardi. 1990. Seblang dan Gandrung: Dua Bentuk Tari Tradisi di Banyuwangi. Jakarta: Pembina Media Kebudayaan.

Rahmat, Jalaluddin. 2005. Psikologi Agama. Bandung: Mizan.

Rahwat, dkk. 7-10 Juli 2011. Hasil Wawancara. Banyuwangi.

Santosa, Eyang. 24 Juli 2011. Hasil Wawancara. Banyuwangi.

Subagyo, Hadi. 1998. Fungsi Ritual Seblang. Tesis Universitas Gajah Mada.

Subkhi. 9 Juli 2011. Hasil Wawancara. Banyuwangi.

Sunyoto, Agus. 2011. Wali Songo Rekonstruksi Sejarah yang Disingkirkan. Jakarta: Transpustaka

Supriyadi. 13 Februari 2011. Hasil Wawancara. Banyuwangi.

Suseno, Franz Magnis. 2003. Etika Jawa Analisa Falsafi tentang Kebijaksanaan Hidup Jawa. Jakarta: Gramedia.

Suyono, Capt. R.P. 2007. Dunia Mistik Orang Jawa. Yogyakarta: LKiS.

Suwarko. 17 Februari 2011. Hasil Wawancara. Banyuwangi.

Warsito. 9 Juli 2011. Hasil Wawancara. Banyuwangi.

Zaehner, R.C. 2004. Mistisisme Hindu Muslim. Terj.Suhadi. Yogyakarta: LKiS 